Iwona Jesion*, Maria Leontowicz ${ }^{* *}$, Hanna Leontowicz ${ }^{* *}$, Mikołaj Gralak**, Yong-Seo Park $^{* * *}$, Shela Gorinstein ${ }^{* * * *}$

\title{
The influence of "Hayward" kiwi fruit (Actinidia deliciosa) from organic and conventional cultivations on the content of some trace elements in the rat kidneys and assessment of copper, manganese and zinc bioavailability
}

\author{
Wpływ owoców kiwi "Hayward" (Actinidia deliciosa) z upraw ekologicznej \\ i konwencjonalnej na zawartość niektórych mikroelementów w nerkach \\ szczura i ocena biodostępności manganu, miedzi i cynku
}

\footnotetext{
${ }^{*} \mathrm{Dr}$ inż. Iwona Jesion, Department of Biology of Animal Environment, Faculty of Animal Science, Warsaw University of Life Sciences, Ciszewskiego 8 St., 02-786 Warsaw, Poland, Phone: +48 225936612 ,

E-mail: iwona_jesion@sggw.pl

${ }^{* *}$ Dr Maria Leontowicz, prof. dr hab. Hanna Leontowicz, prof. dr hab. Mikołaj Gralak, Department of Physiological Sciences, Faculty of Veterinary Medicine, Warsaw University of Life Sciences, Nowoursynowska 159

St., 02-776 Warsaw, Poland, Phone: +48 22 5936264, +48 225936269 ,

+48 22 5936245, E-mail: maria_leontowicz@sggw.pl,

hanna_leontowicz@sggw.pl,gralamikolaj@yahoo.co.uk
}

***Prof. dr hab. Yong-Seo Park, Department of Horticultural Sciences, Mokpo National University, Muan Jeonnam 534-729, South Korea,

E-mail: ypark@mokpo.ac.kr

****Prof. dr hab. Shela Gorinstein, The Institute for Drug Research, School of Pharmacy, Hadassah Medical School, The Hebrew University of Jerusalem, Jerusalem 91120, Israel, E-mail: gorin@cc.huji.ac.il

Keywords: "Hayward" kiwifruit, organic and conventional cultivation, copper, zinc, manganese, kidneys, bioavailability, rats Słowa kluczowe: owoce kiwi, uprawa ekologiczna i konwencjonalna, miedź, cynk, mangan, nerki, biodostępność, szczury

\section{Abstract}

The conditions of fruit cultivation may affect their content of some mineral elements. The study aims at determining the content of some microelements ( $\mathrm{Cu}, \mathrm{Zn}$ and $\mathrm{Mn}$ ) in diets with "Hayward" kiwifruits from the organic (ecological) $(\mathrm{OHC})$ and conventional $(\mathrm{CHC})$ cultivation and also determining their effect on the mineral profile of the kidneys of rats loaded for 28 days with a diet containing $1 \%$ of cholesterol (C) and the assessment of bioavailability of these elements in rats. The mineral composition of the diets and kidneys was examined using a flame atomic absorption spectrophotometer (Perkin-Elemer 1100B). The bioavailability of $\mathrm{Cu}, \mathrm{Zn}$ and $\mathrm{Mn}$ was calculated using the "three-point assay" [Littell et al. 1995]. In the atherogenic diets containing $5 \%$ of "Hayward" kiwifruit, the content of the investigated elements was higher than in the control diet and the highest content was noted in the diet with kiwifruit from the ecological cultivation. The content of $\mathrm{Mn}, \mathrm{Cu}$ and $\mathrm{Zn}$ in rat kidneys was $1.1-1.4,8.2-8.4$ and $36.8-42.4 \mathrm{mg} / \mathrm{kg}$, respectively. The bioavailability of $\mathrm{Cu}$ determined in respect to the $\mathrm{C}$ group was significantly lower in both $\mathrm{CHC}$ and $\mathrm{OHC}$ groups, whereas $\mathrm{Mn}$ was lower only in the $\mathrm{OHC}$ group. There were no significant differences in $\mathrm{Zn}$ bioavailability. The obtained results of the bioavailability of selected trace elements, determined on the basis of their concentration in the rat kidneys, did not show a clear evidence of the advantages of organically cultivated "Hayward" kiwifruit over conventional cultivation, in spite of their different contents in the examined fruits.

(c) IOŚ-PIB

\section{INTRODUCTION}

Kiwifruits are characterised by a number of valuable properties [Duttaroy and Jorgensen 2004; Jung et al. 2005; Park et al. 2006]. They are the source of vitamins, mostly vitamin $\mathrm{C}$, as well as mineral components ( $\mathrm{Cu}, \mathrm{Fe}, \mathrm{Mg}, \mathrm{Zn}, \mathrm{Ca}, \mathrm{Mn}, \mathrm{K}$ and $\mathrm{Na}$ ) [Nishiyama et al. 2004; Park et al. 2006]. The oldest and also the most popular cultivar of Actinidia deliciosa is "Hayward", which also contributed to the popularisation of that fruit in the world. Depending on the growth conditions, application of plant protection agents, artificial fertilisers or the lack of them, plants developed various protective

\section{Streszczenie}

Warunki uprawy owoców mogą mieć wpływ na zawartość w nich składników mineralnych. Celem pracy było określenie zawartości niektórych mikroelementów ( $\mathrm{Cu}, \mathrm{Zn}, \mathrm{Mn})$ w dietach z udziałem owoców kiwi Hayward z uprawy ekologicznej i konwencjonalnej oraz określenie ich wpływu na profil mineralny nerek szczurów obciażonych przez 28 dni dieta z cholesterolem (1\%) oraz ocena biodostępności tych pierwiastków u szczurów. Skład mineralny diet i nerek zbadano przy użyciu płomieniowego spektrometru absorpcji atomowej (Perkin-Elmer 1100B). Do obliczenia biodostępności $\mathrm{Cu}, \mathrm{Zn}, \mathrm{Mn}$ zastosowano model „three-point assay” [Littell i in. 1995]. W dietach z 5\% dodatkiem owoców kiwi Hayward stwierdzono wyższą zawartość badanych mikroelementów względem diety kontrolnej, najwyższą w diecie z kiwi z upraw ekologicznych. Zawartość Mn, Cu i Zn w nerkach szczurów mieściła się w przedziale odpowiednio: 1,1-1,4; 8,2-8,4 i 36,8$42,4 \mathrm{mg} / \mathrm{kg}$. Biodostępność Cu określona względem grupy $\mathrm{C}$ była istotnie niższa w obu grupach $\mathrm{OHC}$ i CHC natomiast Mn tylko w grupie OHC. W biodostępności Zn nie wykazano istotnych różnic. Uzyskane wyniki biodostępności wybranych mikroelementów, określonej na podstawie ich stężenia w nerkach szczurów, nie wskazuja jednoznacznie na przewagę ekologicznej uprawy owoców kiwi Hayward nad konwencjonalną, mimo różnej ich zawartości w badanych owocach. traits. "Hayward" kiwifruits originating from ecological cultivations where only natural fertilisers were used were characterised by thicker peel and smaller flesh surface [Amodio et al. 2007] and were firmer than kiwi from the conventional cultivations [Hasey et al. 1997]. However, Benge et al. [2000] revealed that kiwi from conventional cultivations did not differ in firmness but were characterised by a higher content of soluble stable substances. A global demand for ecologically produced food constantly increases despite the lack of a clear opinion about the advantage of these 
products over those produced conventionally. Various conditions of cultivation (the use of pesticides versus organic fertilisers) may affect the plant and fruit concentration of vitamins, minerals, nitrates and polyphenols [Worthington 2001; Lombardi-Boccia 2004; Amodio et al. 2007; Park et al. 2013].

The aim of this study was to investigate whether the presence of kiwi fruits in a diet, originating from various cultivations, affects the mineral metabolism of a rat fed a diet containing cholesterol. A particular ability for the cumulation of some elements is revealed by the liver and kidneys of animals. The present study aimed at determining the content of $\mathrm{Mn}, \mathrm{Cu}$ and $\mathrm{Zn}$ in the rat kidneys and uses them for calculating their bioavailability in the organism. In the case of $\mathrm{Cu}$, the liver is a better source for estimating the bioavailability of this trace element and these results will be published soon [Leontowicz et al. in press]. Zinc, copper and manganese are among the elements that are considered to be essential, as their presence conditions a proper course of metabolic processes and their deficit or excess leads to serious disturbances of the health state [Kośla et al. 2004; Skibniewski et al. 2010, Skibniewska et al. 2012].

\section{MATERIALS AND METHODS}

Kiwifruit (Actinidia deliciosa) of "Hayward" cultivar were collected from the Muan area in South Korea (National University, Muan, Jeonnam, South Korea). The experiment was performed on the ecological and conventional plantations. In the ecological plantation, an organic method was applied, which excludes the use of pesticides and synthetic fertilisers. The soil was only enriched by organic matter (bird droppings). Chemicalisation in the form of synthetic mineral fertilisers and plant-protecting agents were used on the conventional plantation. Fruits were thoroughly washed under the running water and then dried, peeled, weighed, chopped up and homogenised in a high-speed mixer (Hamilton Beach Silex professional model) for a minute. Kiwifruit samples were freezedried for $48 \mathrm{~h}$ (Virtis model 10-324). Fruits comprised $5 \%$ of the semisynthetic diet with $1 \%$ of cholesterol added.

The experimental model comprised the male Wistar rats fed the diet containing cholesterol for 28 days. The animals were divided into three groups: control $(\mathrm{C})$ and two experimental $\mathrm{CHC}$ - with kiwi fruits from the conventional cultivations included in the diet and $\mathrm{OHC}$ with the share of fruits from ecological cultivations. The content of the investigated microelements in the diets and kidneys was determined using a flame atomic absorption spectrophotometer (Perkin-Elemer 1100B). The bioavailability of these elements was calculated using the "three-point assay" [Littell et al. 1995]. That model was used after a prior observation in particular groups a rectilinear dependence $(y=a+b x)$ between the concentration of the element in the organ $(y)$ and its consumption $(x)$.

One-way analysis of variance for statistical evaluation of results was used, followed by Duncan's test to assess differences in group's means; in the case of some elements bioavailability, Scheffe's test was used. Results were expressed as arithmetic means \pm standard deviation (SD).

\section{RESULTS AND DISCUSSION}

A growing interest in "healthy food" contributes to the appearance of new ecological farms in which the plant-protecting agents or artificial fertilisers are not applied [Carey et al. 2009]. It seems that such a population of "healthy food" among the consumers results from the belief that it is safer for people and the environment. However, the views concerning a high health value of ecological food are controversial. According to some authors, ecological food is more healthy, according to some others it does not differ from food produced using the plant-protecting agents [Brandt and Molgaard, 2001; Dangour et al. 2009; Stracke et al. 2009].

While analysing the mineral composition of the experimental diets, no significant differences in the content of $\mathrm{Mn}, \mathrm{Cu}$ and $\mathrm{Zn}$ were observed, only an increasing tendency was noted in the diets containing "Hayward" kiwifruit (Table 1). The lowest content of the investigated elements was noted in the control diet (C) and the highest in the diet supplemented with kiwi fruits from the ecological cultivation. In the rat kidneys from the $\mathrm{CHC}$ group, the highest $\mathrm{Mn}$ content was obtained, which was significantly $(P \leq 0.05)$ different from the $C$ group (Table 2). Similar results were obtained in the rat liver [Leontowicz et al. in press]. The highest $\mathrm{Zn}$ content in kidneys was noted in the $\mathrm{OHC}$ group, significant $(P \leq 0.05)$ in relation to the $\mathrm{C}$ and $\mathrm{CHC}$ group. The copper content in the rat kidneys was equal in all groups and on the average amounted to $8.3 \mathrm{mg} / \mathrm{kg}$.

Most publications concerning conditions of the conventional or ecological cultivation are devoted only to fruits [Anttonen and Karjalainen 2006; Wang et al. 2008] and there are only some informing about their effect on human beings and animals. There are many factors affecting the absorption of $\mathrm{Mn}, \mathrm{Cu}$ and $\mathrm{Zn}$, which may be both activators and inhibitors of that process. What is more, most elements demonstrate synergistic or antagonistic action towards each other [Kośla et al. 2004; Skibniewska et al. 2012]. It is suggested that the effect of kiwi fruits on the bioavailability of

Table 1. The content of the investigated elements in the diets of rats $(\mathrm{mg} / \mathrm{kg})$

\begin{tabular}{|l|c|c|c|}
\hline Diets & Mn & $\mathrm{Cu}$ & \multicolumn{2}{|c|}{$\mathrm{Zn}$} \\
\hline $\mathrm{CHC}$ & $11.0 \pm 1.5$ & $11.8 \pm 1.5$ & $90.4 \pm 3.1$ \\
\hline $\mathrm{OHC}$ & $12.1 \pm 2.9$ & $12.3 \pm 0.9$ & $101.2 \pm 4.9$ \\
\hline $\mathrm{C}$ & $9.8 \pm 1.5$ & $10.3 \pm 1.2$ & $89.1 \pm 0.2$ \\
\hline
\end{tabular}

Mean \pm SD (standard deviation), $n=5$. The lack of letters means the lack of differences between means $(P>0.05)$. CHC - a diet with $1 \%$ cholesterol content and $5 \%$ supplement of kiwi fruits from conventional cultivations; OHC - a diet with $1 \%$ cholesterol content and $5 \%$ supplement of kiwi fruits from ecological cultivations; $\mathrm{C}$ - semisynthetic diet with the addition of $1 \%$ cholesterol.

Table 2. The content of the investigated elements in the rat kidneys $(\mathrm{mg} / \mathrm{kg})$

\begin{tabular}{|l|l|l|l|}
\hline Groups & $\mathrm{Mn}$ & $\mathrm{Cu}$ & $\mathrm{Zn}$ \\
\hline $\mathrm{CHC}$ & $1.4 \pm 0.2 \mathrm{~b}$ & $8.3 \pm 0.7$ & $37.1 \pm 1.5 \mathrm{a}$ \\
\hline $\mathrm{OHC}$ & $1.2 \pm 0.1 \mathrm{ab}$ & $8.4 \pm 0.5$ & $42.4 \pm 3.9 \mathrm{~b}$ \\
\hline $\mathrm{C}$ & $1.1 \pm 0.1 \mathrm{a}$ & $8.2 \pm 0.5$ & $36.8 \pm 3.8 \mathrm{a}$ \\
\hline
\end{tabular}

Mean $\pm \mathrm{SD}$ (standard deviation), $n=6$; means in columns marked with different letters differ among themselves in a statistically significant way $(P \leq 0.05)$. The lack of letters means the lack of differences between means $(P>0.05)$. CHC - animals from a group fed with the diet containing $1 \%$ share of cholesterol and $5 \%$ addition of kiwi fruits from the conventional cultivations; $\mathrm{OHC}$ - animals from a group fed with the diet containing $1 \%$ share of cholesterol and $5 \%$ addition of kiwi fruits from ecological cultivations; $\mathrm{C}$ - animals from the control group, fed with a diet containing $1 \%$ cholesterol. 
the chosen elements may be connected with the presence of other components in a diet (cholesterol) or in fruits themselves (vitamin C, polyphenols and tannin) [Siegenberg et al. 1991; Salgueiro et al. 2000]. It was revealed that also the dietary fibre, whose valuable source are fruits and vegetables, has the hypolipidemic properties, decreases the absorption of food cholesterol and bile acids [Leontowicz et al. 2001; Duttaroy and Jorgensen 2004], but it also affects the decrease of the iron, calcium, zinc and copper absorption [Gralak et al. 2004]

A significant drop of manganese and copper bioavailability determined on the basis of the concentration of those elements in kidneys was obtained in rats fed with the diet with the addition of kiwi fruits from ecological cultivation towards the $C$ group (Fig. 1), which was the reference group and comprised $100 \%$. In the case of relative bioavailability determined on the basis of the liver, similar results were obtained [Leontowicz et al. in press]. The manganese bioavailability in the $\mathrm{OHC}$ group was significantly lower
$(P \leq 0.05)$ than in the $\mathrm{CHC}$ group (Fig. 1$)$; the results of bioavailability obtained on the basis of the concentration of that element in the liver also confirm that difference although it was not statistically significant [Leontowicz et al. in press]. A decreasing tendency of zinc bioavailability in both the groups containing kiwi fruits in relation to the $\mathrm{C}$ group was also demonstrated (Fig. 1).

\section{CONCLUSIONS}

- The addition of $5 \%$ "Hayward" kiwifruit into the atherogenic semisynthetic diet caused the increase in the dietary content of the investigated elements: $\mathrm{Mn}, \mathrm{Cu}$ and $\mathrm{Zn}$ without significant differences resulting from different conditions of the kiwifruit (Actinidia deliciosa) cultivation.

- The conditions of "Hayward" kiwifruit cultivation did not have a significant effect on the investigated microelements bioavailability.

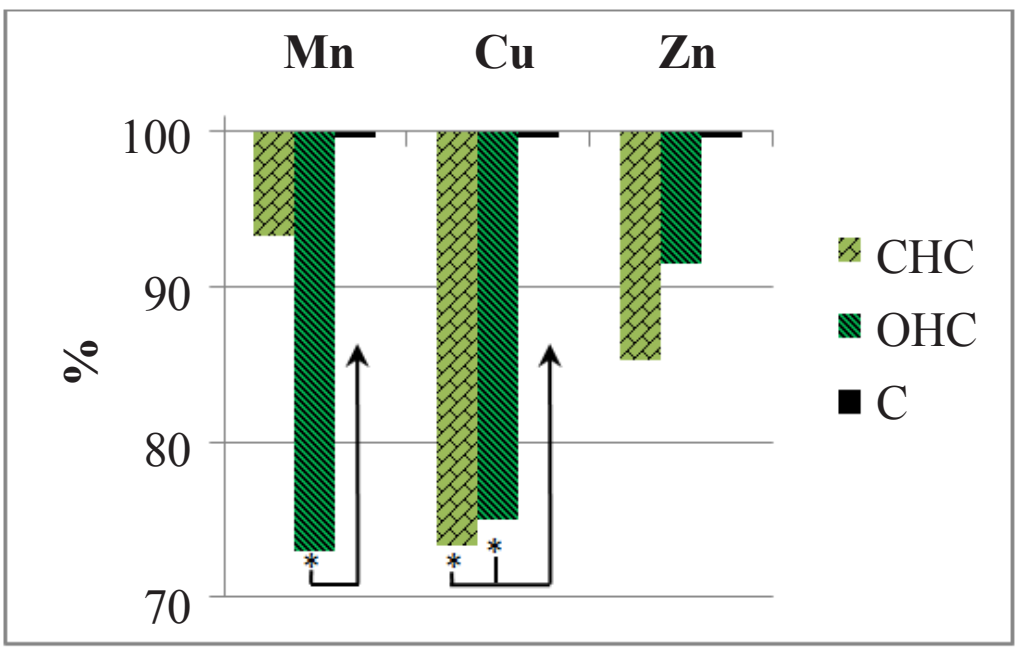

Fig. 1. The relative bioavailability (\%) of the investigated elements: $\mathrm{Mn}, \mathrm{Cu}$ and $\mathrm{Zn}$.

\section{REFERENCES}

AMODIO M.L., COLELLI G., HASEY J.K., KADER A.A. 2007. A comparative study of composition and postharvest performance of organically and conventionally grown kiwifruits. Journal of the Science of Food and Agriculture 87:1228-1236.

ANTTONEN M.J., KARJALAINEN R.O. 2006. High-performance liquid chromatography analysis of black currant (Ribes nigrum L.) fruit phenolics grown either conventionally or organically. Journal of Agricultural and Food Chemistry 54: 7530-7538.

BENGE J.R., SILVA H.N., BANKS N.H., JEFFREY P.B. 2000. Empirical modelling of postharvest changes in the firmness of kiwifruit. Postharvest Biology and Technology 19: 211-220.

BRANDT K., MØLGAARD J.P. 2001. Organic agriculture: does it enhance or reduce the nutritional value of plant foods? Journal of the Science of Food and Agriculture 81: 924-931.

CAREY P.L., BENGE J.R., HAYNES R.J. 2009. Comparison of soil quality and nutrient budgets between organic and conventional kiwifruit orchards. Agriculture, Ecosystems and Environment 132: 7-15.

DANGOUR A. D., DODHIA S.K., HAYTER A., ALLEN E., LOCK K., UAUY R. 2009. Nutritional quality of organic foods: a systematic review. The American Journal of Clinical Nutrition 90: 680-685.
DUTTAROY A.K., JORGENSEN A. 2004. Effects of kiwi fruit consumption on platelet aggregation and plasma lipids in healthy human volunteers. Platelets 15: 287-292.

GRALAK M.A., LEONTOWICZ H., LEONTOWICZ M., STRYCZEK A., PIASTOWSKA A.W. 2004. The effect of apple pulp on bioavailability of zinc and copper from atherogenic diets in rats. In: Anke M., Flachowsky G., Kisters K., Schafer U., Schenkel H., Seifert M., Stoeppler M. (Eds.) Mengen- und Spurenelemente, First Volume, 22. Workshop, Schubert-Verlag Leipzig, Germany, 106-111.

HASEY J.K., JOHNSON R.S., MEYER R.D., KLONSKY K., SFAKIOTAKIS E., PORLINGIS J. 1997. An organic versus a conventional farming system in kiwifruit. Acta Horticulturae 444, 223-238.

JUNG K-A., SONG T-C., HAN D., KIM I-H., KIM Y-E, LEE C-H. 2005. Cardiovascular protective properties of kiwifruit extracts in vitro. Biological and Pharmaceutical Bulletin 28: 1782-1785.

KOŚLA T., SKIBNIEWSKI M., SKIBNIEWSKA E., URBAŃSKASŁOMKA G. 2004. The zinc status in free living european bisons. Acta Alimentaria 33: 269-273. 
LEONTOWICZ M., JESION I., LEONTOWICZ H., PARK Y.S., NAMIEŚNIK J., JASTRZĘBSKI Z., KATRICH E., TASMAZ., GORINSTEIN S. 2013 (in press.). Organic and conventional kiwifruit supplementation could influence the bioactivity and bioavailability of minerals in rats loaded with cholesterol. Microchemical Journal. LEONTOWICZ M., GORINSTEIN S., BARTNIKOWSKA E., LEONTOWICZ H., KULASEK G., TRAKHTENBERG S. 2001. Sugar beet pulp and apple pomace dietary fibers improve lipid metabolism in rats fed cholesterol. Food Chemistry 72: 73-78.

LITTELL R.C., LEWIS A.J., HENRY P.R. 1995. Statistical evaluation of bioavailability assay. In: Ammerman C.D., Baker D.H., Lewis A.J. Bioavailability of nutrients for animals: amino acids, minerals, and vitamins. Academic press limited, London 5-31.

LOMBARDI-BOCCIA G., LUCARINI M., LANZI S., AGUZZI A., CAPPELLONI M. 2004. Nutrients and antioxidant molecules in yellow plums (Prunus domestica L.) from conventional and organic productions: a comparative study. Journal of Agricultural and Food Chemistry 52: 90-94.

NISHIYAMA I., YAMASHITA Y., YAMANAKA M., SHIMOHASHI A., FUKUDA T., OOTA T. 2004. Varietal difference in vitamin C content in the fruit of kiwi fruit and other Actinidia species. Journal of Agricultural and Food Chemistry 52: 5472-5475.

PARK Y.S., IM M.H, HAM K.-S., KANG S.-G., PARK Y.-K., NAMIESNIK J., LEONTOWICZ H., LEONTOWICZ M., KATRICH E., GORINSTEIN S. 2013. Nutritional and pharmaceutical properties of bioactive compounds in organic and conventional growing kiwifruit. Plant Foods for Human Nutrition 68: 57-64.

PARK Y.S., JUNG S-T., KANG S-G., DRZEWIECKI J., NAMIESNIK J., HARUENKIT R. 2006. In vitro studies of polyphenols, antioxidants and other dietary indices in kiwifruit (Actinidia deliciosa). International Journal of Food Sciences and Nutrition 57: 107-122.

SALGUEIRO M.J., ZUBILLAGA M., ŁYSIONEK A., SARABIA M. I., CARO R., PAOLI T., HAGER A., WEILL R., BOCCIO J. 2000. Zinc as an essential micronutrient: a review. Nutrition Research 20: 737-755. SIEGENBERG D., BAYNES R.D., BOTHWELL T.H., MACFARLANE B.J., LAMPARELLI R.D., CAR N.G., MACPHAIL P., SHMIDT U., TAL A., MAYET F. 1991. Ascorbic acid prevents the dose-dependent inhibitory effect of polyphenols and phytate on non-heme iron absorption. American Journal of Clinical Nutrition 53: 537-541.

SKIBNIEWSKA E., SKIBNIEWSKI M., KOŚLA T. 2012. Dependence between $\mathrm{Cu}$ concentration in the liver, kidneys and sceletal muscles of canine females. Central European Journal of Biology 7: 817-824.

SKIBNIEWSKI M., KOŚLA T., SKIBNIEWSKA E.M. 2010. Manganese status in free ranging European Bisons from Białowieża primeval forest. Bulletin of the Veterinary Institute in Pulawy 54: (3), 429-432.

STRACKE B.A., RUÖFER C.E., BUB A. 2009. No effect of the farming system (organic/conventional) on the bioavailability of apple (Malus domestica Bork., cultivar Golden Delicious) polyphenols in healthy men: a comparative study. European Journal of Nutrition 49: 301-310.

WANG S.Y., CHEN C.T., SCIARAPPA W., WANG C.Y., CAMP M.J. 2008. Fruit quality, antioxidant capacity, and flavonoid content of organically and conventionally grown blueberries. Journal of Agricultural and Food Chemistry 56: 5788-5794.

WORTHINGTON V. 2001. Nutritional quality of organic versus conventional fruits, vegetables, and grains. Journal of Alternative and Complementary Medicine 7: 161-173. 